\title{
CHALLENGES AND OPPORTUNITIES ASSOCIATED WITH DEVELOPMENT OF SMALL AND MEDIUM ENTERPRISES IN JAFFNA DISTRICT
}

\author{
Vaikunthavasan $\mathrm{S}^{1}$, Velnampy $\mathrm{T}^{2} \&$ Rajumesh $\mathrm{S}^{3}$ \\ University of Jaffna \\ Sathana08@jfn.ac.lk1,tvnampy@yahoo.co.in²,rajumesh3@yahoo.com ${ }^{3}$
}

\begin{abstract}
With the globalization trend, Small and Medium Enterprises (SMEs) are in rapidly growing and developing arena. It has momentous influences on the prolific changes in all countries, and they are major contributor for inclusive economic growth, regional development, employment generation and poverty reduction in Sri Lanka. This research was conducted to diagnose the awesome challenges and opportunities of SMEs in the existing situation of Jaffna District. Further this paper reviewed the existing literature, empirical studies as well as the prevailing data bases in order to identify the challenges and opportunities for the development of SMEs in the Jaffna District. Researcher conducted qualitative exploratory research; explain the phenomenon of problematic situation of SMEs in Jaffna District. Purposive sampling technique was the sampling method, primary data collection method was used to collect the data, and structured interview was conducted with the 37 heads of community development institution in the Jaffna district. This study revealed that end of the war crafted peace environment in Sri Lanka, Many problems and challenges are faced by SMEs in Jaffna District in this post war situation, SMEs in Jaffna District are in the embryonic stage comparing with SMEs in other district in Sri Lanka and there are vast opportunities and unutilized resources for industrial expansions in this SME sector in Jaffna District. This industrial enlargement will create more market opportunities to the SMES. The important implication of this study is that the SME sector is envisaged opportunities to contribute to transform lagging regions into emerging regions of prosperity.
\end{abstract}

Keywords: Challenges and opportunities, Development, Small and Medium Enterprises (SMEs)

\section{INTRODUCTION}

Small and Medium Enterprises (SMEs) are the prime business sectors in Sri Lanka. The Government of Sri Lanka recognizes SMEs as the backbone of the economy, as it accounts for more than $75 \%$ of the total number of enterprises, provides $45 \%$ of the employment and contributes to $52 \%$ of the 
Gross Domestic Production (GDP) (National policy Framework for SME Development, 2015). SMEs promote broad based equitable development and provide more opportunity for women and youth participation in the economic development of the country. There are believes that sustainable development can only be achieved by addressing issues of full and fair employment. SMEs are an essential source for employment opportunity. There are few mass industries and many SMEs in Jaffna District. Local war created huge unbelievable marks for the Jaffna District. SMEs in Jaffna District have been recovering from the war wounds. There are many efforts to reconstruct and rehabilitate the school, banks, roads, power and energy and other key infrastructure in Jaffna District. SME development must be complemented by job creation, growth and sustainability. SME development is gauged by the financial performance, market performance and employment. There is unutilized huge level of flora and fauna resources in Jaffna district, particularly the agriculture, fisheries, education, service, infrastructure, industry, animal husbandry, health care and tourism are the identified sectors for investment opportunities. SMEs have high opportunity to develop and at the same time they have to face big challenges to succeed and survive in the environment. This prevailing changing and challenging environment need to adopt the marketing strategies for the development of the SMEs. The poor attitudes and less innovative means of the SMEs are backlog in its improvement. This research try to identify the challenges from prevailing environment which are sustained by the SMEs and the major opportunities for growth of SMEs in Jaffna district.

\section{SIGNIFICANCE OF THE STUDY}

SMEs play a vital role for the blossoming development of the nation and they are significant forces in world economy. The composition of the European business landscape is that only $0.2 \%$ of all European businesses are large scale, $6.9 \%$ of European business are medium scale, $1.1 \%$ of European business are small scale and $91.8 \%$ of all EU businesses are micro scale (ESBA, 2011).

Poverty and employment are the persisting problems in those economies in developing countries. SME sector of Sri Lanka has not achieved desired level of contribution when compared with other developed and developing countries (Gamage, 2003). SME development in Sri Lanka is embarrassed by number of factors, in the research of Nishantha \& Padmasiri (2010), the essential factors negatively affected the performance of small enterprises in a remote district of Sri Lanka. After the war huge displacement of people, damaged infrastructure, poor education and in-security prepared very low GDP contribution from Jaffna District. Even though in the Northern province (NP) $90 \%$ of business are under the SMEs sector, the contribution of GDP of NP is only $3.4 \%$ in 2010, 3.7\% in 2011 (CBSL, Press release, 
2012), this is very lower level compared with the contribution of other provinces and huge level of graduates are unemployed in Jaffna district. There is rapid resettlement for displaced people. Infrastructure and other services has been provided to pick up life and move on. Even though rapid resettlement was focused and conducted, rural areas in Jaffna district are still struggling with basic infrastructure and all other essential facilities. The growth and expansion of SMEs in Jaffna district are constrained by problems emanating from product and factor markets and the regulatory system they operate in. Furthermore many challenges have been faced to develop the SMEs in Jaffna district. There are multi-faceted opportunities prevailing in the SME sector, they are to promote balanced regional development, improvement in the overall investment climate, foreign direct investment, creating a strong backward linkage between SMEs and agricultural sector. SMEs can be in progress with low investments, and more labor per unit of capital employed implying and promoting this sector offers huge employment opportunities.

\section{RESEARCH GAP}

Kapurubandara\& Lawson (2006) presented a model for barriers to adoption of Information Communication Technology (ICT) and e-commerce for SMEs in Sri Lana, collected from the available literature and the results of an exploratory pilot studies and subsequent survey. Inaddition to the barriers facing SMEs, this research identified the relevant support required by SMEs in a developing country, Sri Lanka. Priyanath \& Premaratne (2014) analyzed the activities of each SME development program being currently implemented by the Sri Lankan government, employing qualitative content analysis to understand whether they facilitate to access information and to select appropriate governance mechanism. The study recognized that SME development programs of Sri Lanka do not positively contribute to develop a favorable transaction environment for SMEs. Business Development Centre (SLBDC) to carry out a research study in 2002 on the opportunities and challenges faced by the Sri Lankan Small and Medium Size Enterprises (SMEs) in adapting e -commerce into their daily business routines.

Nishantha \& Padmasiri (2010) examine the current role of SMEs in different industries, as well as understanding their contribution to the economy and identify the possibilities for promoting SMEs in the Sri Lanka. The paper goes further to review the existing literature, empirical studies as well as the prevailing data bases in order to identify the challenges and opportunities for the development of SMEs in the post conflict era. The study found that there is a vast opportunity for Sri Lanka to harness the opportunity by developing this vital sector. Gamage (2003) provide a brief overview of SME sector in Sri Lanka, and to make suggestion for enhancing the capacities of 
SMEs for a sustainable development in Sri Lanka. Kirushanthy (2015) carried out to understand the main causes of the business failure of SMEs in Baticaloa district.

SMEs sustain major role all over the world. There are many researchers in worldwide regarding challenges and the development of the SMEs. SMEs have a big role in Sri Lanka. The first policy of ministry of industry and commerce is going to create enabling environment to the development of SME in Sri Lanka. After the local war, Jaffna district is recovering and growing steadily, SMEs in Jaffna District has been struggling with many problems and challenges. This research try to identify whether there is enabling environment or not for Development of SMEs by addressing the challenges faced by SMEs in Jaffna district. Further The SME Policy Framework will support start-up SME enterprises, strengthen the existing enterprises and extend nursing programmes for potentially viable sick SMEs. In Jaffna district, it is very important to diagnose the challenges and problems of start-up enterprises, existing enterprises, and sick enterprises. Very few researchers were involved in conducting research regarding SMEs covering all part of the country and very few researches were conducted regarding the SMEs in Jaffna District .Effects of internal and external factors are not studied for SMEs in Sri Lanka. Many countries have been diagnosing and evaluating the problematic situation and challenges in different industries, but there is no one study available to diagnose challenges and problematic situation of SMEs in Jaffna district. Hence it is very important to study the challenging factors for SMEs developments and there is also need to study the opportunities for SMEs in Jaffna district. This study will focus to identify the major challenges from problematic environment and opportunities for SMEs in Jaffna district with the qualitative perspective.

\section{LITERATURE REVIEW}

\subsection{Small and Medium Enterprises (SME's)}

Collectively, micro-businesses, small businesses and medium sized firms are referred to as SMEs (SME: Back born of the Economy, 2003). SMEs are defined in a variety of ways by various countries using such parameters such as number of persons employed, amount of capital invested, amount of turnover or nature of the business, etc. According to the recent guidelines issued by the Central Bank of Sri Lanka, SME is defined as enterprises that have an annual turnover less than Rs 600 million and its borrowings below Rs 200 million (CBSL, 2012). The Sri Lanka Export Development Board (SLEDB) for export oriented enterprises, SMEs are defined as those enterprises with a capital investment excluding land and buildings of less than Rs 8 million or with annual export turnover of less than Rs 50 million (Gamage,2003).In the Sri Lankan context, the SME policy framework defines SMEs based on the 
number of employees and annual turnover, it is displayed by the table 1 .

\subsection{Development of SME}

SMEs play important role in any economy through generation of employments, contributing to the growth of GDP, Embarking on innovations and stimulating of other economic activities. This sector is said to be the backbone of all developed and developing nations. SMEs are often observed to have different organizational Goals/ effectiveness as profitability, sales, sales growth rate, market share, net profit, gross profit, cash flow, return on investment, product innovation, and process innovation (Irina, 2008).Itis seen as a driver of change for inclusive economic growth, regional development, employment generation and poverty reduction. SME sector is envisaged to contribute to transform lagging regions into emerging regions of prosperity (National policy frame work for SME development, 2015)

\subsection{Challenges for Development of SMEs}

This SME Policy Framework will broadly set out the policy direction, the challenges to be addressed and the broad intervention strategies. The major policy intervention areas are identified into six core areas namely enabling environment, modern appropriate technology, entrepreneurial culture and skills development, access to finance, market facilitation and research and development. Also it is important to focus on the regional balance and resource efficiency in developing SMEs (National policy frame work for SME development, 2015)

The challenges for the development of SMEs are financial capital, infrastructure, employment opportunity, greater utilization of machinery, equipment and raw materials and intellectual and skill employees, subcontracting with formal and informal sectors (Gamage, 2003). In the external context, environmental regulation, government incentives for innovation and environmental actions, environmental protection, supply chain impacts their environmental strategic decisions and technological competence are also considered as challenges. They must be managed jointly and interactively between the barriers and drivers in the adoption of environmentally friendly practices and technologies. Internal factors that lead to eco-innovation management were also analyzed. In general, the support of the company's senior management, which becomes crucial for decision making in this field, the skills and capabilities of technological absorption of companies, which provide the necessary conditions for this adoption, the more its culture and features are so modified, with the internalization of environmental preservation. Furthermore, certain intervening variables were also considered, which may affect the organizations, such as the organization's size, age, origin of capital and market of operation (Maçaneiro\& da Cunha, 2014). 
The main problems that small and medium enterprises encounter, especially during the start-up phase, deal with the lack of financial resources and also with administrative barriers in terms of bureaucracy. The SMEs in developing countries fall behind with adoption due to barriers, both internal and external, prominent and inherent in a developing country as Cultural, Infrastructure, Political, Social, and Legal and Regulatory Barriers. Interpretation of preliminary internal barriers: such as the lack of skills required and the lack of awareness of any return on investment (Kapurubandara \& Lawson, 2006)

\section{RESEARCH QUESTION}

SMEs have high opportunity to develop the business at the same time they face big challenges to succeed and survive in the environment.

1. What are the existing challenges faced by SME in Jaffna District?

2. What are the opportunities associated with the development of SMEs in Jaffna District?

\section{RESEARCH OBJECTIVES}

1. To identify the existing challenges for SMEs in Jaffna district

2. To find out the opportunities associated with development of SMEs in Jaffna district.

\section{METHOD}

This study was applied qualitative methodology. Qualitative research was concerned with developing explanations of social phenomena in this study. Researcher conducted exploratory research and used exploration of the existing certain phenomena. It analyzes the practices of existing and ideas to the future. This research describes the "subjective reality" of a system; it is the study of a phenomenon. The analysis of embodied lived experience for instance is rooted in phenomenology and phenomenologists forego coding of data all together. Researchers following the interpretive paradigm where the above listed sequential analyses techniques belong to even perceive coding as an abhorrent incompatible act for data analysis.

\subsection{Sample}

This study was conducted in Jaffna districts in Sri Lanka. The unit of analysis in this study is SME related officers of the government and non government institutions in the Jaffna District. Population is infinite for this study and comprises of all SME related officers in the Jaffna district. This research followed the purposive sampling method. The sampling units may be individuals or they may be in groups. Each member of sampling frame is called sampling unit. Each SME related officerswere sampling units in this research. Sample was considered 37 different kind of SME related officersin Jaffna District and the subjects were presented in the annexure. 


\subsection{Instrument Development}

Primary data collection method was utilized in this research. Data collection instrument was the semi structured interview method. Researcher utilized the ideas of previous research to develop the questions (Gamage, 2003; Perera \& Wijesinha, 2011). It consisted of series of open ended questions and broad questions. The interview question was displayed with the annexure. Further secondary data was gathered from Journals, articles in newspapers, books, SMEs publication and reports, central bank reports and publications, and government organizations' data banks and publications.

\section{DATAANALYSIS}

Researcher utilized NVivo software of QRS international. Interview was conducted using audio recording, then it was translated and transcribed. Initially the themes were pointed as observed or recorded. Then open code and axial coding were applied to code the data. The open coding is the researcher identification and then second order coding by using in-vivo called as first order coding. Then the axial coding was revealed the themes of second - order from first coding categories. The second order themes were revealed as emergent framework base on Corley and Gioia, 2004. There are table 5 displaying in-vivo codes and first order, second order and findings respectively in the annexure.

\subsection{Reliability and validity}

Researcher utilized NVivo (version 11) to extract subjects' records, transcript and other related document. Proportional reduction in loss method was used to assess the reliability of coding scheme. The current study was 0.729 , which is well above the 0.7 cut-off level recommended for exploratory research (Rust and Cooil, 1994).

The validity of this research was presented as five (Silverman and Marvasti, 2008). First the respondent validation, researcher shared the findings with the study subjects and discuss opinion of them regarding the interpretation and credibility of findings. Second refutability was disproved by having diverse subjects to collect the data. Third constant comparison was made by displaying the additional research and expanded data collection to validate emergent findings. Forth under the comprehensive data treatment, researcher examine the data again and again to draw the comprehensive suggestions and conclusions. The fifth deviant-case all interviews was recorded and translated properly without any deviant cases by using NVivo software to manage the data and findings properly.

\section{RESULT AND DISCUSSION}

In discussing the questions, subjects have given most valuable information of this study.
9.1 The interaction of institutions with SMEs in Jaffna District 
Government and non- government institutions are providing the services for the SMEs in Jaffna district. Researcher has identified these services as three: Basic/ essential services, Development services and Assistances.

The basic services are registration of business, issuing environmental certificates and quality standard certificate and PHI (Protected Health Information) certificates and EPF \& ETF services.

Development and supportive services are awareness workshops and programs regarding Labor rules and regulations, environmental regulations or greener product, quality standard products, new machinery and instrument purchase, technology transfer and value added to product. Further it includes export advices, financial literacy regarding loans, technology adaptation knowledge, budget and business planning, technical upgrading plan, ideas of technical expert regarding Material, machinery, technology, and product upgrading, structure and layout creation ideas and sustainable market ideas. They encourage to upgrade micro entrepreneur to small, small to medium, women and student participation in entrepreneurship.

Assistances which are offered for SMEs are market opportunities, e-commerce training and facilities, export link, professional training, field visit, research assistances, attitude blast counselling, forums regarding financial, marketing and management development, fund assistances, business link-for supplier, producer and distributor and local, national, and international exhibition.

\subsection{The most challenging SMEs and contributing SMEs in Sri Lanka}

All micro, small and medium entrepreneurs are facing problems, but based on the business type the problem vary. All of the respondents have accepted that micro entrepreneurs are facing huge problems, only $60 \%$ of respondents have accepted that small entrepreneurs are also facing huge problems.

The $90 \%$ of respondents have accepted that both small entrepreneurs are the most important contributors for the nation, only $10 \%$ of respondents have accepted that only medium entrepreneurs are the most important for the nation.

\subsection{Challenges for SMEs}

\subsubsection{Political and Legal Challenges}

According to answer of the respondents political challenges are instability in SME policy over the period of time, poor legal literacy, labor low barriers regarding EPF and ETF, undefined wag level for employees, approval of patent copyright and quality standards in Jaffna district, poor compensation to displaced entrepreneur to restart or recover from post war situation, poor SME policy 
implementation, restriction to get the loan, political vulnerability, no separate tax system to war affected Jaffna District, many procedure for registration of business, child labor law restriction and inadequate fund allocation and consideration for research and development sector by government. Further huge area of usable land is in the hand of government after the local war. Thereis high requirement to get quality standard as GMP (Goods manufacturing process), SLS(Sri Lanka Standard) and ISO (International standard organization).The Policies regarding the educational and professional qualifications for SME business are not defined well, this leads to unstandardized productions and services from SMEs.

\subsubsection{Economic Challenges}

The most of the entrepreneurs are facing financial difficulties. Further increasing inflation leads to high labor cost, raw material and other cost, high cost of production, low margin, increase in price, and decrease in demands for products. Thereis floating exchange rate, risk in foreign export income, foreign aids and donations. The entrepreneurs arepoor financial literacy regarding loan utilizations and loan repayment, favorable loan scheme but in practice many documentary and guarantee requirements. There is very poor mediaassistances, high advertising cost, and Limited working capital to SME.

\subsubsection{Sociocultural challenges}

There is no gender based equality in salary and also in type of works in SMEs. Males are dominant mostly as entrepreneur and women are assisting to them, very rare participation of women. Mobilityto get raw material and market access are limited to women. Tamil \& Muslims women are restricted to participate independently in SMEs. Most of the entrepreneurs have negative attitude regarding their growth and development, they are risk avoiders, easy earning expectation and not future perspective thinking.

Most of the SEMs are involving in traditional based production method and no any innovative or creative production method. Education to community in Jaffna district is in adequate level but career development opportunity is weak, so they can earn limited income and sustain restricted life style. Education, professional qualification and IT knowledge of Micro entrepreneur is very low. Media awareness, web, internet, networking knowledge is very poor to SME employees in Jaffna District. Workload for employees is high, high absenteeism and labor turnover are high.

\subsubsection{Technological challenges}

SMEs in Jaffna district are technology back, lack of innovated machinery, mostly manual based productions, poor quality, low amount, high cost, poor packaging and poor diversification in products. Most of SMEs have traditional based productions, and no Nano technology adoptions. Further they haven't upgraded technology, web based emarketing, social network marketing system 
and poor media support to convey the proper message to SMEs.

\subsubsection{Green environmental challenges}

The entrepreneurs in Jaffna district are struggling problems with environmental certification regarding air, emission, noise and vibration, waste water and solid waste, sea food quota system to fishery industry, environment balance, occupational safety and health, greener production inducement, organic productions and raw materia lexploitation. SMEs have to be certified under stringent food safety, quality management, environmental management, health and safety and social accountability standards. Moreover our processing factories are recognized among the finest water and carbon conscious facilities.

\subsubsection{Competitive challenges}

The entrepreneurs are in problematic competitive situation, because the SMEs in Jaffna district are in embryonic stage, manual productions, having poor quality, finishing and packaging, poor diversification of products, low output, no efficient and effective productions, no economies of scale, low consumer switching cost, only short term market success, questionable survival, poor research and development, high energy cost, no any market research to identify the consumers' needs, wants, styles and new trends properly, internally inadequate strength, risk avoiding manner of entrepreneur, no innovated technology adoption and poor media awareness and reach. SMEs are in weak position to compete locally, nationally and internationally.

The consumers are not knowledgeable and poor health conscious to consume healthy, organic and greener products. Then there is poor advertising, promotional tools and poor media availability to the products, this leads to failure of business.

\subsection{Opportunities to develop the SMEs in Jaffna District}

Researcher conceptualized these opportunities as five different prospects: a) Human resource, b) adequate demand and inadequate supply, c) adequate demand, and not quality products and d)tourism attractiveness e) under exploited resources Huge Human resource, and high entrepreneur ship skills are available in Jaffna district. There is adequate demand and inadequate supply such as fruits, palmyrah fiber, coconut fiber and ships, sweet toddy, milk, gee, curd, Chess, mango, sea food, sea leech, crab, sea weeds, leather product, grapes, wine, plums, mash rooms, aleovera, cucumber, big size peanut, Water pump productions and gherkins.

There is adequate demand but not quality products by proper value additions as coffee, yogurt, milk based panner, grapes, wine, plums, coconut flour, desiccated coconut, creamed coconut and coconut sugar, pineapple, mango, papaya and banana either in cans/jars or in a dehydrated manner. There is attractive and potential locations, beaches and marine land for tourism in Delft and 
other sea shores.

Unexplored or under exploited resources are palmyrah based tooth paste and jelly, seedless big grapes, jumbo peanut, Banana bubble gum, sunflower, neem oil, medicinal plants, floriculture industry, bio-fertilizer and bio-pesticides industries.

\subsection{Suggestions to face the challenges}

The remarkable and valuable participants related to SMEs gave some suggestion regarding the improvement by the following way. Government must allocate more money from treasury to develop SMEsto create huge research and development center to conduct research on existing resource utilization. Government must encourage every educated people to get involve in entrepreneurship by offering tax free or tax reduction, interest rate reduction, and subsidiary assistances for involving in entrepreneurship. Now in Sri Lanka, anyone can begin and involve in desired production or services anytime, but in foreign countries, anyone can't involve in entrepreneurship without adequate educational and professional qualification, it is very important standardize the educational and/ or professional qualification to involve in SMEs. Now there is no government institutions to check the quality standards, offer the patent and copyright in Jaffna district, it is very important to bring the facilities to Jaffna district. Science and technology officers are assigned to DS officers to offer scientific and technological assistances for entrepreneurships, but only Journal of Business Studies few staffs are assigned to Jaffna district at the same time, government fails to offer adequate resources and training to them, other foreign countries are spending more money on these research and development. Internet facilities in Jaffna district is very poor, so government must offer high quality network facility to Jaffna district to have proper communication ande-commerce adaptation for SMEs. In Jaffna district SEMs have adequate print media and one telecasting media, but these Medias have only small participation for SMEs, so it is very important to create high participative broadcast, print, and telecast of Medias to SMEs growth and development in Jaffna district. Further collaborative work of government, nongovernmental organizations, University and entrepreneur, partnerships with the private sector for SME development is very essential in Jaffna district. The involvement of undergraduate and postgraduate students in SME related research is essential in Jaffna district. Creating entrepreneurship as a specialized degree in Universities will be the big responsible to government by offering assistances to bring the student as an entrepreneur. The high value addition to the SME product to capture the local, national and export market is very essential. Facilitators must create awareness about new pattern, attractive designs, verified quality and modern style by having field trips and showing international products. Furthermore facilitators must offer financial literacy and technology upgrading literacy to change the attitude of entrepreneurs.
Issue I - 2016 
Government or NGOs or international companies can sponsor prospective industry, develop proper working and production environment in Jaffna district. All provincial ministers and all other politicians involve to improve the SMEsin Jaffna district. Facilitators encourage the ecofriendly product and award to best producer in every type of industry and create recognition and high popularity to the quality product through all Medias encourage to produce organic product.

\section{CONCLUSION AND RECOMMENDATION}

Present study identified three interactions of government and non-government with the SMEs in Jaffna district such as basic services, development services and assistances. Further the study revealed that micro entrepreneurs are facing huge problems and challenges and small entrepreneurs are contributing highly for the nation in Jaffna district. The challenges are dimensioned as political and legal, economical, socio cultural, technological, environmental and competitive factors. Subjects revealed the five different prospects as opportunities, they are human resource, adequate demand but inadequate supply, adequate demand but not quality products and Tourism attractiveness.

Even though there are huge level of unutilized, and underutilized resources in Jaffna district, positive policy making by the government to develop SMEs in
Sri Lanka, adequate level direct and supportive services of government bodies, some financial grant assistance from government and NGOs, SMEs business are still problematic, struggling and embryonic stage. Researcher identified the reasons and problems root for the SMEs and some solutions which was suggested by the subjects. In addition to this, the remarkable solutions were also recommended by the researcher.

Last 30 years people in Jaffna district sustained unforgettable wounds by local war, it is very hard to pull up and bring them to a smooth successive level. With their bad experience, all entrepreneur can only think about short term, they can't think about long term and sustainability. First they want to realize that they are in safety and good prospected environment, it is very important to create self-confidence, positive attitude and challenging and risk taking habits. Then only they will involve successfully in their production or business. That is a big bridge building programs. Government must allocate more money to science and technology and research and development. Further collaborative work of government, non government, university and entrepreneurs are very important to the 
long term sustainable development of SMEs. Furthermore standardization of educational or professional qualification and wage or salary level to employees creates more strength concrete to the development of SMEs. Now a days Media is power full tool to convey the information to public, hence print Medias must plan to allocate reasonable page and telecast and broadcast media must allocate a particular time to convey the information regarding the SMEs. Infrastructure development like information technology, harbor, airport and low cost energy energize smooth operations and supply chain to the SMEs. All these awesome suggestions for the SME sector are envisaged the opportunities to contribute for transforming lagging regions into emerging regions of prosperity.

\section{REFERENCES}

CBSL, 2012, Press release of Statistics Department.

Corley, K, G,.\&Gioia, D,A. (2004). Indentify ambiguity and change in the wake of a corporate Spin-off. Adminidtrative Science Quarterly, 29, 173-208

ESBA (2011), Micro and small Business in the EU, European Small Business Alliance drived form http://www.esbaeurope.org/

Gamage, A. S. (2003). Small and Medium Enterprise Development in Sri Lanka:
A Review. Meijo University, Faculty of Business Management, Nagoya, Japan.

Kapurubandara,M and Lawson, R (2006), Barriers to Adopting ICT and ecommerce with SMEs in Developing Countries: An Exploratory study in Sri Lanka, School of Computing and Mathematics, University of Western Sydney, Australia

Kirushanathy,K. (2015) Factors contributing to the failure of the Small, Medium scale Enterprises: A survey based study in Manmunai North Divisional Secretariat DivisionBatticaloa District, Proceeding of International Conference on contemporary Management, (ICCM) pp 471-486

Maçaneiro, M. B., \& da Cunha, S. K. (2014). Theoretical Analysis Model of the Adoption of Reactive and Proactive Eco-Innovation Strategies: the Influence of Contextual Factors Internal and External to Organizations. BBR-Brazilian Business Review, 11(5), 1-23.

National policy Framework for Small Medium Enterprise (SME) Development, (2015). Ministry of Industry and commerce

Nishantha, B., \&Padmasiri, H. N. (2010).

Development of Small and Medium Enterprises in Post Conflict Sri Lanka: Opportunities, Challenges and Policy Implications.

O'Dwyer, M., Gilmore, A., \& Carson, D. 
(2009). Innovative marketing in SMEs.European Journal of Marketing, 43(1/2), 46-61.

Olujide, J. O., \&Bamidüro, J. A. (2003). Elements of Marketing Management I.

Perera.D and Wijesinha.A (2011), SME

Development Strategies for Sri Lanka:

Learning Lessons from Neighboring

Countries

Peterson,R. (1982), Marketing, A Contemporary Introduction, Kreger publishing Copmpany Malabar, Florida.

Priyanath, H, M,S. and Premaratne, S, P.(2014) Government SME Development Programs in Sri Lanka: A Review in the Lens of Transaction Cost Economics, Sabaragamuwa University Journal, Vol13(2), pp 59-81

Rust, R. T., \&Cooil, B. (1994). Reliability measures for qualitative data: Theory and implications. Journal of Marketing Research, 1-14.

Silverman, D., \&Marvasti, A. (2008). Doing qualitative research: a comprehensive research: a comprehensive guide. Thousand Oaks, CA: Sage

SLBDC (2002).Sri Lanka Business Development Centre, Survey on ECommerce Implementation in the SME Sector of Sri Lanka, The Asia Foundation

SME: Back born of the Economy, 2003. The Sunday times, business times

Tang, Z., \& Hull, C. E. (2011). The strategy configuration of Chinese SMEs. Journal of Enterprising Culture, 19(03), 229-259.
Venkatraman, N., \&Ramanujam,V.(1986). Measurement of business performance in strategy research: a comparison of approaches. Academy of Management Review.

Wijesinha.A ,2011, SME Development Strategies for Sri Lanka: Learning Lessons from Neighbouring Countries, Talking Economics

Wijetunge, W. A. D. S. Strategic Planning Practices of Manufacturing Small and Medium Scale Enterprise 
Table 1: Defining SMEs in Sri Lanka

\begin{tabular}{|c|c|c|c|c|}
\hline $\begin{array}{l}\text { Size } \\
\text { Sector }\end{array}$ & Criteria & Medium & Small & Micro \\
\hline $\begin{array}{l}\text { Manufacturing } \\
\text { Sector }\end{array}$ & al Turnover & $\begin{array}{l}\text { Rs. Mn. } 251 \text { - } \\
750\end{array}$ & Rs. Mn. $16-250$ & $\begin{array}{l}\text { Less than Rs. } \\
\text { Mn. } 15\end{array}$ \\
\hline & No of employees & $51-300$ & $11-50$ & Less than 10 \\
\hline Ser & Annual Tumover & $\begin{array}{l}\text { Rs. Mn. } 251 \text { - } \\
750\end{array}$ & Rs. Mn. $16-250$ & $\begin{array}{l}\text { Less than Rs. } \\
\text { Mn. }\end{array}$ \\
\hline & No. of Employees & $51-200$ & $11-50$ & Less than 10 \\
\hline
\end{tabular}

Source: National policy frame work for SME development, 2015

Table 2: Subjects of the research \$

\begin{tabular}{|l|l|}
\hline Institution of Respondents & No officers \\
\hline IDB - industrial development Board & 1 \\
\hline CB- Regional Manager & 1 \\
\hline $\begin{array}{l}\text { Chief Executive Officer- Chamber of } \\
\text { Commerce }\end{array}$ & 1 \\
\hline UNDP & 1 \\
\hline Department of Industry & 1 \\
\hline Export development Board & 1 \\
\hline
\end{tabular}

\begin{tabular}{|l|l|}
\hline NECTA- Assistant Director & 1 \\
\hline NEDA- Provincial Director & 1 \\
\hline GIZ & 1 \\
\hline ILO & 1 \\
\hline DS & 8 \\
\hline Export development Board officer & 5 \\
\hline NEDA officer & 5 \\
\hline Rural economic affairs & 3 \\
\hline Euro will & 1 \\
\hline Environmental officer & 1 \\
\hline Vocational training authority officer & 1 \\
\hline Incubation cell-faculty staff & 1 \\
\hline University business Linkage & 1 \\
\hline Science and Technology Officer & 1 \\
\hline
\end{tabular}

Table 3: Research interview questions

\begin{tabular}{|l|}
\hline Interview question \\
\hline Q1. Are you dealing with SME, If yes in which way? \\
\hline Q2. Which type of SME is the most important for the nation; Small, medium or micro? \\
\hline Q3. Which type of entrepreneur are facing huge problems, Small, medium or micro? \\
\hline Q4.what are the challenges faced by SMEs in Jaffna district \\
\hline Journal of Business Studies 78
\end{tabular}


Q5. Can you give any solution or support to solve the problems, If yes, what are they? Q6. Are there any opportunities to develop the SMEs (industry) in Jaffna district? If yes, What are they?

Table 4: in-vivo codes, first- order categories and second order themes

\begin{tabular}{|c|c|c|c|}
\hline In vivo codes & $\begin{array}{l}\text { First order } \\
\text { categories }\end{array}$ & $\begin{array}{l}\text { Second order } \\
\text { theme }\end{array}$ & Interactions \\
\hline $\begin{array}{l}\text { Registration of business } \\
\text { Issuing environmental certificates } \\
\text { and quality standard certificate PHI } \\
\text { certificates and } \\
\text { EPF \& ETF services. }\end{array}$ & $\begin{array}{l}\text { Essential } \\
\text { services }\end{array}$ & Authorized services & $\begin{array}{l}\text { Basic } \\
\text { services }\end{array}$ \\
\hline $\begin{array}{l}\text { Awareness workshops and programs } \\
\text { regarding Labor rules and } \\
\text { regulations, environmental } \\
\text { regulations or greener product, } \\
\text { quality standard products, new }\end{array}$ & $\begin{array}{l}\text { Progressive } \\
\text { ideas and } \\
\text { knowledge }\end{array}$ & $\begin{array}{l}\text { Sustainable ideas } \\
\text { and knowledge }\end{array}$ & $\begin{array}{l}\text { Development } \\
\text { services }\end{array}$ \\
\hline $\begin{array}{l}\text { machinery and instrument purchase, } \\
\text { technology transfer and value added } \\
\text { to product. } \\
\text { Export advices, financial literacy } \\
\text { regarding loans, technology } \\
\text { adaptation knowledge, budget and } \\
\text { business planning, technical } \\
\text { upgrading plan, ideas of technical } \\
\text { expert regarding material, } \\
\text { machinery, technology, and product }\end{array}$ & & & \\
\hline
\end{tabular}




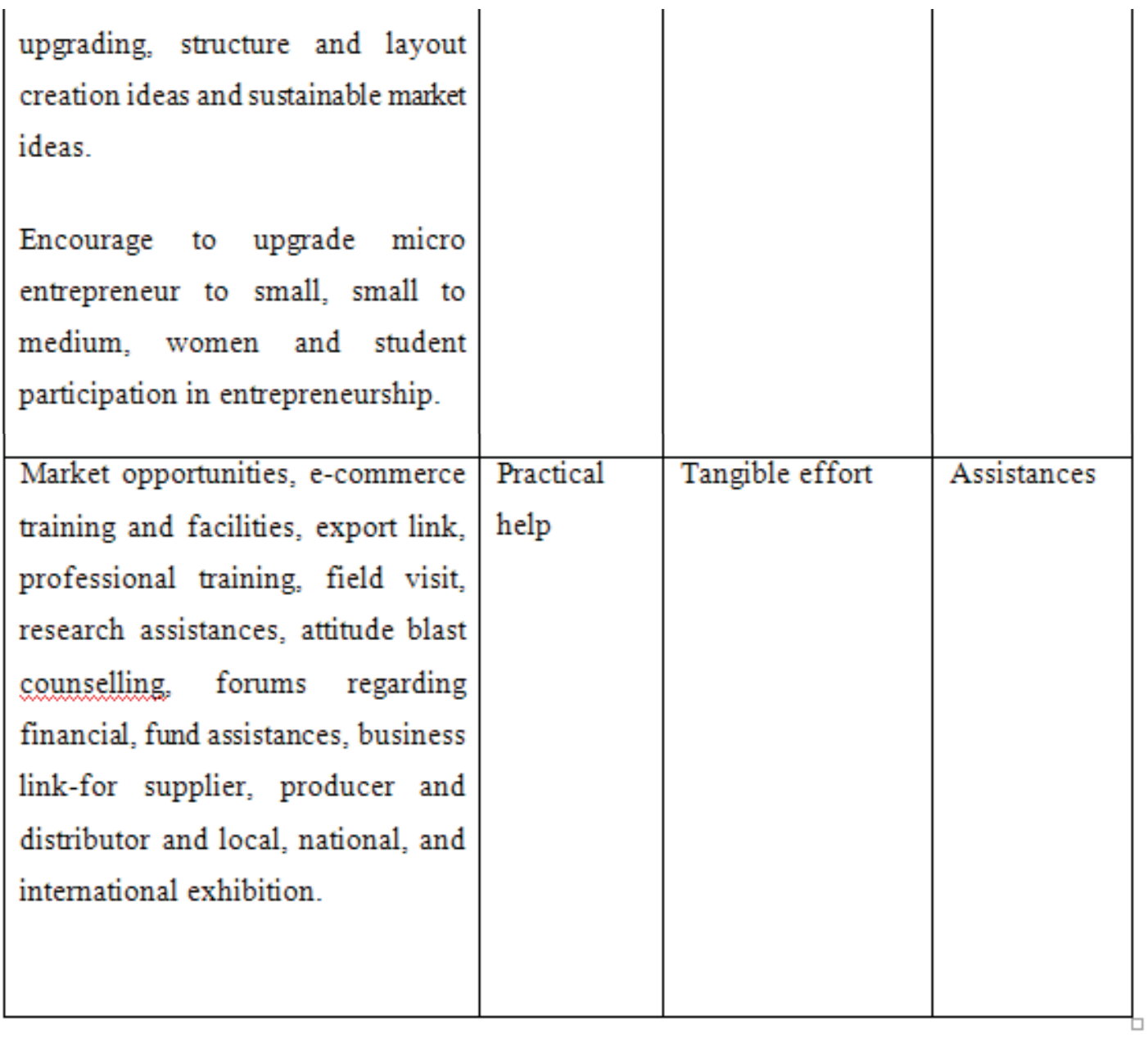

